\title{
Peningkatan Nutrisi Pupuk Organik Cair Dari Limbah Pemurnian Minyak Nilam Menggunakan EM4
}

\author{
Titien Sara ${ }^{1 *}$, Syaifullah Muhammad ${ }^{2}$, Sri Aprilia $^{3}$ \\ ${ }^{1}$ Program Studi Teknik Kimia, Universitas Serambi Mekkah, Banda Aceh \\ ${ }^{2,3}$ Program Studi Teknik Kimia, Universitas Syiah Kuala, Banda Aceh
}

*Koresponden email : saratitin_sarah@yahoo.com

Diterima: 21 Desember 2020

Disetujui: 22 Maret 2021

\begin{abstract}
Production of patchouli oil refining the largest waste in Indonesia but still has a high nutrient content and can be used as liquid organic fertilizer. To increase the efficiency of the formation of liquid fertilizer from patchouli waste requires the role of the EM4 bioactivator and chicken manure. The study aims to determine the production of liquid organic fertilizer from patchouli waste with EM4 bioactivator and the addition of chicken manure as well as to analyze the effect of the fermentation time and EM4 solution to obtain a maximum content of $\mathrm{N}, \mathrm{P}, \mathrm{K}$. The results showed that there was some effects of fermentation time and variable of EM4 on NPK content. The maximum solution of $\mathrm{N}$ in the variable solution 8\% EM4 with a 3-day fermentation time was $0.34 \%$. The maximum $\mathrm{P}$ in the $4 \%$ EM4 variable solution with a 9day fermentation time was $0.10 \%$. The maximum $\mathrm{K}$ in the $2 \%$ and $4 \%$ EM4 variable solution with a 5day fermentation time was $0.27 \%$.
\end{abstract}

Keywords: patchouli oil refining waste, bioactivator, EM4, NPK

\begin{abstract}
Abstrak
Produksi limbah penyulingan minyak nilam di Indonesia cukup tinggi dan masih mempunyai kadar hara yang tinggi dan dapat dimanfaatkan menjadi pupuk organik cair. Untuk meningkatkan efisiensi pembentukan pupuk cair dari limbah nilam memerlukan peranan bioaktivator EM4 dan kotoran ayam. Penelitian ini bertujuan untuk mengetahui pembuatan pupuk cair yang berasal dari limbah nilam dengan bioaktivator EM4 dan penambahan kotoran ayam dan menuganalisa pengaruh volume waktu fermentasi dan voleme EM4 untuk memdapatkan kadar N, P, dan K maksimum. Hasil penelitian menunjukkan pengaruh waktu fermentasi dan EM4 terhadap kadar NPK. Kadar nitrogen $(\mathrm{N})$ maksimum pada variabel EM4/ larutan 8\% dengan waktu fermentasi 3 hari yaitu 0,34\%. Kadar fosfor (P) maksimum pada variabel EM4/ larutan $4 \%$ dengan waktu fermentasi 9 hari yaitu $0,10 \%$. kadar kalium (K) maksimum pada variabel EM4/larutan 2 dan $4 \%$ dengan waktu 5 hari yaitu $0,27 \%$.
\end{abstract}

Kata Kunci : limbah penyulingan minyak nilam, bioaktivator, EM4, nilam, NPK

\section{Pendahuluan}

Tanaman nilam (Pogostemon cablin benth.) adalah salah satu jenis tanaman penghasilan minyak astiri yang penting di Indonesia. Besarnya volume limbah nilam seringkali menjadi masalah bagi pihak industri pengolahan minyak nilam itu sendiri. Maupun lingkungan. Hasil samping dari penyulingan minyak nilam adalah limbah yang terdiri dari ampas sisa daun dan batang. Pupuk cair dapat menghasilkan dari fermentasi tumbuhan dan kotoran hewan secara alami sehingga masyarakat dapat membuat sendiri dan pupuk organik cair telah banyak digunakan dibandingan pupuk padat. Hal ini disebabkan pupuk organik cair memiliki beberapa kelebihan, antara lain lebih mudah tersedia, bersifat ramah lingkungan (tidak merusak tanah dan tanaman), memiliki larutan pengikat sehingga dapat diaplikasi pada tanaman, cepat diserap oleh akar dan daun tanaman [1].

Penggunaan pupuk organik cair memiliki kelebihan dapat memperbaiki strukur tanah sehingga tanah menjadi gambur, meningkatkan daya serap tanah terhadap air karena dapat meningkat air lebih banyak, pembaiki kehidupan biologi tanah, dan unsur hara di dalam pupuk organik cair merupakan makanan bagi tanaman dan sumber unsur hara N, P, dan K. Pemberian pupuk organik cair dengan konsentrasi berimbang berpengaruh terhadap kandungan hara dalam tanah yang akan diserap tanaman untuk melakukan pertumnuhan [2]. Salah satu permasalahan pokok yang dihadapi sebagaian besar tanah di Indonesia yaitu kekurang akan unsur hara, khususnya unsur hara mikro yang sangat diperlukan oleh tanaman untuk meningkatkan hasil dan daya tahan tanaman terhadap serangan hama dan penyakit. 
Kekurangan unsur hara mikro ini tidak dapat dipenuhi oleh pupuk kimia yang umumya hanya mengandung beberapa unsur hara makro saja [3] .

Dalam penelitian ini akan dilakukan proses ferementasi limbah nilam dengan penambahan limbah kotoran ayam dan penambahan bakteri Effective Microorganisme (EM4) dapat meningkatkan unsur hara. Penambahan EM4 berfungsi untuk meningkatkan kandungan humus tanah sehingga mampu menguraikan bahan organik menjadi asam amino yang mudah diserap oleh tanaman dalam waktu cepat. Apabila pupuk organik cair tersebut disemprotkan pada tanaman, akan meningkatkan jumlah klorofil sehingga akan berpengaruh pada proses fotosintesis [4]. EM4 mengandung banyak sekali mikroorganisme pemecah bahan-bahan organik. EM4 juga dapat meningkatkan penyerapan unsur hara, karena EM4 dapat meningkatkan penyerapan karbohirdrat dan beberapa unsur lainnya, bahan-bahan organik seperti N, P, dan K yang dibutuhkan tanaman, tetapi tidak dapat diserap langsung oleh tanaman. Senyawa tersebut perlu dipecah menjadi bentuk ion-ion yang mudah diserap tanaman. Penelitian ini bertujuan untuk memaksimumkan kadar unsur N,P, dan K [5].

\section{Metode Penelitian}

\section{Waktu dan Tempat Penelitian}

Penelitian dilakukan di laboratorium Program Studi Teknik Kimia, Universitas Syiah Kuala Banda Aceh selama 14 hari tahun 2021. Alat yang digunakan wadah plastik, termometer, gelas ukur, selang, penyaringan limbah. Sementara bahan yang digunakan adalah bioaktivator EM4, air suling (aquadest), limbah minyak nilam yang berasal dari Kabupaten Aceh Jaya, dan kotoran ayam yang diperoleh dari peternakan kawasan Kota Aceh Besar.

\section{Prosedur Kerja}

\section{Preparasi Sampel}

Sampel yang digunakan pada penelitian ini adalah limbah hasil penyulingan minyak nilam atau ekstrak nilam kering dan penambahan pupuk organik dari kotoran ayam. Kemudian wadah plastik (komposter), air suling digunakan sebagai pelarut, dan kemudian ditambahkan aktivator EM4 sesuai dengan variabel yang telah divariasikan ke dalam komposter.

2. Pembuatan Pupuk Organik Cair

Limbah penyulingan minyak nilam dilakukan pengecilan ukuran terlebih dahulu dengan menggunakan proses penggilingan. Kemudian dimasukkan ke dalam wadah plastik/komposter volume 15 liter sebanyak $1 \mathrm{~kg}$, tambahkan kotoran ayam sebanyak $0,5 \mathrm{~kg}$, serta dimasukan activator EM4 sesuai variasi masin-masing ke dalam komposter, setelah itu ditutup rapat, dan disimpan ditempat yang teduh agar terhindar dari sinar matahari langsung. Pengujian sampel pupuk cair dilakukan selama proses penelitian dengan rentang waktu 3,5,7, dan 9 hari. Proses Analisa uji parameter kadar NPK terhadap kandungan pupuk organik cair menurut SNI 19-7030-2004.

\section{Hasil dan Pembahasan}

\section{Analisa pH dan Temperatur Pupuk Organik Cair Limbah Nilam}

Hasil analis $\mathrm{pH}$ dan temperatur pupuk organik cair limbah nilam dapat dilihat pada Tabel 1.

Tabel 1. $\mathrm{pH}$ dan temperatur pada pupuk cair limbah nilam terhadap variasi volume EM4 dan waktu fermentasi

\begin{tabular}{|c|c|c|c|c|c|c|c|c|}
\hline \multirow{3}{*}{ EM4 (\%) } & \multicolumn{7}{|c|}{ Hari } & \\
\hline & 3 & & 5 & & 7 & & 9 & \\
\hline & $\mathrm{pH}$ & Temp & $\mathrm{pH}$ & Temp & $\mathrm{pH}$ & Temp & $\mathrm{pH}$ & Temp \\
\hline 2 & 4,5 & & 4,5 & & 4,8 & & 5,1 & \\
\hline 4 & 4,5 & $31^{\circ} \mathrm{C}$ & 4,2 & $31^{\circ} \mathrm{C}$ & 4,9 & $31^{\circ} \mathrm{C}$ & 4,9 & $31{ }^{\circ} \mathrm{C}$ \\
\hline 6 & 4,1 & & 5.9 & & 4,9 & & 4,6 & \\
\hline 8 & 4,7 & & 5,9 & & 6,6 & & 6,8 & \\
\hline
\end{tabular}

Sumber: Data hasil penelitian, 2020

Berdasarkan Tabel 1 terlihat bahwa proses awal fermentasi terjadi pada hari ke-3 dengan kisaran pH 4,1-4,7. Hal tersebut dipengaruhi oleh bakteri EM4 yang mengubah makanan menjadi asam organik, pada tahapan proses selanjutnya bakteri EM4 akan mengubah asam organik tersebut mendekati normal. Dalam penelitian ini larutan EM4 memiliki pH 4, sedangkan limbah nilam memiliki pH 9. Menurut SNI pH minimal pupuk organik cair yang direkomendasikan adalah pada kisaran $\mathrm{pH}$ 4-9 [6]. Perubahan $\mathrm{pH}$ yang signifikan terjadi pada volume EM4 6 dan 8\% pada waktu pengomposan mulai 5 hingga 9 hari. Namun pada volume EM4 6\% pada waktu hari ke 3mengalami penurunan $\mathrm{pH}$. Hal tersebut diduga karena 
proses perombakan senyawa organik menjadi asam organik sudah berhenti atau dalam laju yang kecil sehingga nilai $\mathrm{pH}$ tetap atau menurun [7] [8] [9]. Sedangkan pada volume EM4 8\% mengalami peningkatan $\mathrm{pH}$ yang signifikan. Nilai $\mathrm{pH}$ yang baik pada umumnya untuk asam organik sampai netral sekitar 6.5-7,5. Tingkat keasaman $\mathrm{pH}$ merupakan salah satu faktor kritis bagi pertumbuhan mikroorganisme yang terlibat dalam proses pengomposan [1].

Pada penambahan activator EM4, temperatur yang dicapai relatif sama pada seluruh variasi EM4 yaitu $31^{\circ} \mathrm{C}$ seperti yang ditunjukkan pada Tabel 1. Proses pengomposan akan berlangsung dengan baik apabila bahan berada dalam temperatur yang sesuai untuk merombak bahan adalah $35-55^{\circ} \mathrm{C}$. Namun setiap kelompok mikroorganisme mempunyai temperatur optimum yang berbeda, sehingga temperatur optimum pengomposan merupakan integrasi dari berbagai jenis mikroorganisme yang terlibat [10][11].

\section{Analisa Pengaruh EM4 dan Waktu Fermentasi Terhadap Kadar N, P, dan K}

Pengaruh EM4 dan waktu fermentasi terhadap kadar nitrogen yang dihasilkan dapat dilihat pada Gambar 1a. Kadar nitrogen maksimum pada pupuk cair terjadi pada variabel EM4/ larutan 8\% yang mengalami kenaikan cukup signifikan yaitu mencapai $0,34 \%$ dengan waktu fermentasi 3 hari. Pada variabel EM4 2\%, 4\%, dan 6\%, terlihat konsentrasi nitrogen sedikit mengalami kenaikan dan cenderung konstan. Kadar nitrogen maksimum yaitu $0,34 \%$ pada waktu fermentasi 3 hari untuk variasi EM4 8\%, sedangkan pada variasi EM4 yang lainnya kadar nitrogen berkisar 0,10-0,11\% pada waktu fermentasi yang sama. Kadar nitrogen mengalami penurunan yang sangat signifikan pada waktu fermentasi 5 hingga 9 hari untuk variasi EM4 8\% yang disebabkan cadangan makanan telah habis. Serupa dengan penelitian yang dilakukan oleh Ref. [5], kadar nitrogen dalam pupuk organik cair juga diperoleh maksimum pada penambahan EM4 yang maksimum. Pengaruh metabolisme dalam proses fermentasi yang mengakibatkan nitrogen terasimilasi dan hilang melalui volatilisasi sebagai amoniak atau hilang karena proses denitrifikasi sehingga produksi nitrogen meningkat [5] [12].

Berdasarkan Gambar 1b diperoleh peningkatan kadar fosfor secara signifikan terjadi pada masingmasing variasi EM4 seiring dengan kenaikan waktu fermentasi. Pada fase awal, mikroba menyesuaikan diri dan melakukan metabolisme dan aktivitasnya mampu meningkatkan ukuran sel. Selanjutnya sel menggunakan karbon dari limbah minyak nilam sebagai sumber energi dan memperbanyak diri [5].

Penguraian yang semakin baik ditunjukkan dengan semakin meningkatnya kadar fosfor dan berangsur menuju konstan pada hari ke-9. Namun pada EM4 8\%, peningkatan kadar fosfor maksimum terjadi pada hari ke-5 dengan kadar 0,9\%. Hal tersebut diduga karena mikroorganisme menyerap sebagian fosfor untuk membentuk zat putih telur dalam tubuhnya. Kompleks putih telur merupakan salah satu hasil akhir dari pengomposan yang paling penting. Karena kompos dengan penambahan EM4 terbanyak paling cepat matang, maka semakin banyak kesempatan mikroorganisme untuk menyerap sebagian fosfor pada kompos yang telah matang tersebut [13] [14].

Sebagaimana yang ditampilkan pada Gambar 1c, waktu fermentasi maksimum terjadi pada hari ke -5 dengan kadar kalium sebesar 0,27\%: 0,27\%; 0,2\%; dan 0,25\% masing-masing pada volume EM4 2, 4, 6 , dan $8 \%$. Selanjutnya berangsur konstan sehingga waktu fermentasi pada hari ke-9. Unsur kalium akan dimanfaatkan oleh mikroba dalam proses dekomposisi sehingga semakin banyak penambahan EM4 maka akan semakin banyak pemanfaatan kalium oleh mikroba. Namun dalam penelitian ini, kadar kalium maksimum tidak terjadi pada EM4 8\% melainkan terjadi pada EM4 2\% dan $4 \%$ yaitu masing-masing sebesar $0,27 \%$. Hal ini mungkin disebabkan oleh penggunaan karbon sebagai sumber energi dan hilang dalam bentuk $\mathrm{CO}_{2}$ sehingga kandungan karbon semakin lama akan berkurang pada EM4 8\% [5][15]. 


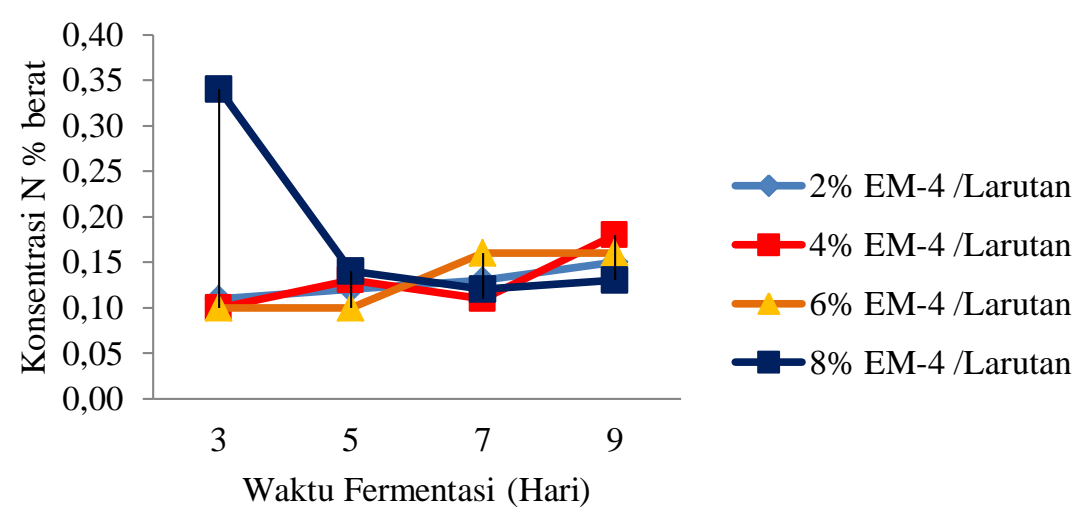

(a)
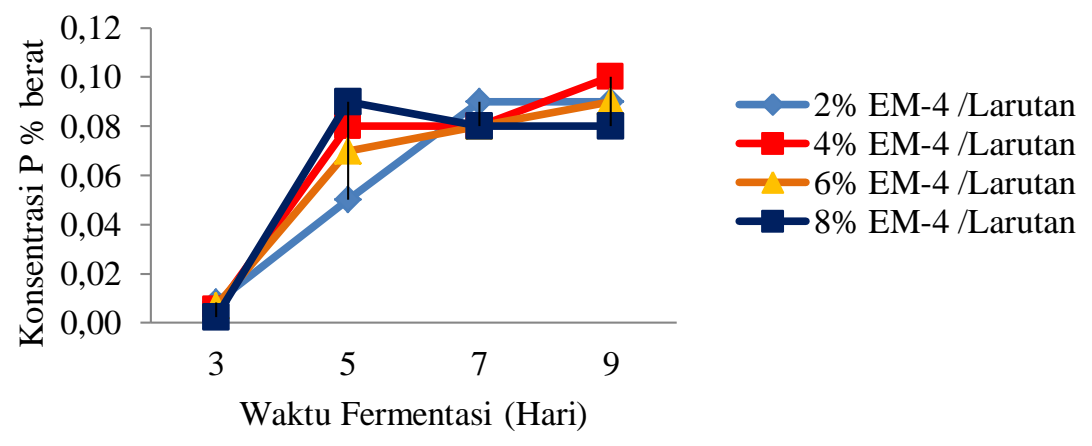

(b)

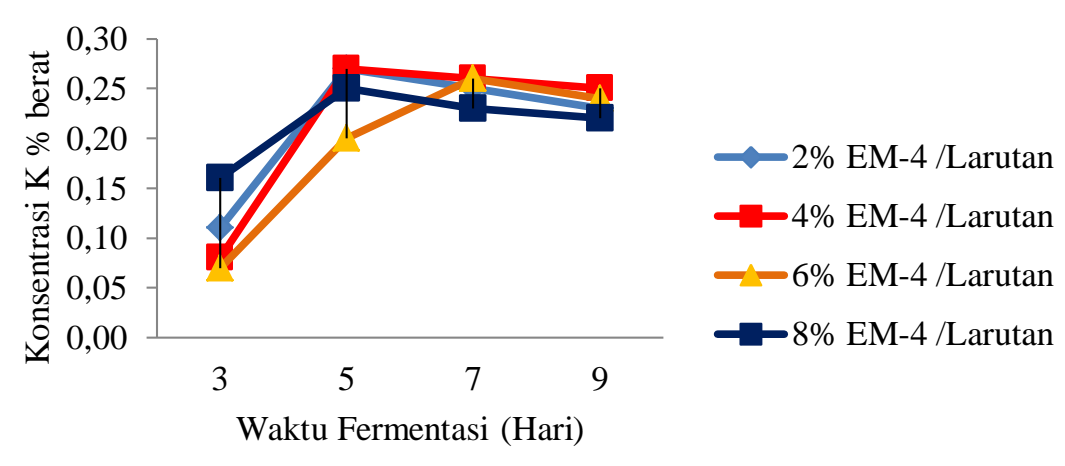

(c)

Gambar 1. (a, b, c) Persentase kadar N, P, dan K terhadap waktu fermentasi pada masing-masing variasi EM4 Sumber: Data penelitian, 2020.

\section{Pengaruh Waktu Fermentasi Terhadap Kandungan Unsur Hara N, P dan K}

Pengaruh waktu fermentasi terhadap kandungan total nitrogen, fosfor, dan kalium pada pupuk organik cair hasil fermentasi limbah penyulingan minyak nilam ditunjukkan pada Gambar 2. Waktu fermentasi yang divariasikan dalam penelitian ini adalah 3, 5, 7, dan 9 hari. Berdasarkan Gambar 2 kandungan unsur hara yang paling banyak terdapat dalam pupuk organik cair dari limbah penyulingan minyak nilam dan kotoran ayam adalah kandungan nitrogen yaitu $0,34 \%$ dan diikuti oleh kandungan kalium sebanyak $0,25 \%$ dan fosfor sebanyak $0,09 \%$.

Unsur hara yang paling banyak terdapat dalam tanaman adalah kandungan nitrogen $(\mathrm{N})$, yaitu sebanyak 2-4 \% dari berat kering tanaman [16]. Semakin lama waktu fermentasi pupuk organik cair, maka kandungan nitrogen akan semakin meningkat [17]. Hal ini terjadi karena semakin lama proses fermentasi maka proses dekomposisi yang dilakukan mikroorganisme akan menghasilkan ammonia dan nitrogen. Tingginya kandungan nitrogen pada waktu fermentasi 9 hari ini disebabkan lama waktu yang tersedia cukup lama untuk dekomposisi substrat limbah penyulingan minyak nilam dan kotoran ayam sehingga $\mathrm{N}$ dihasilkan cukup tinggi dibandingkan kandungan unsur hara makro lainnya. Namun kadar 
nitrogen yang dihasilkan dalam penelitian ini masih rendah dibawah standar pupuk organik cair sebagaimana yang di tampilkan pada Tabel 2.

Tabel 2. Perbandingan kadar unsur hara pupuk organik cair

\begin{tabular}{lcc}
\hline \multicolumn{1}{c}{ Unsur Hara } & SNI & Riset \\
\hline Nitrogen (N) & $3-6 \%$ & $0,34 \%$ \\
Fosfor (P) & $3-6 \%$ & $0,09 \%$ \\
Kalium (K) & $3-6 \%$ & $0,25 \%$ \\
\hline
\end{tabular}

Sumber: Data penelitian, 2020

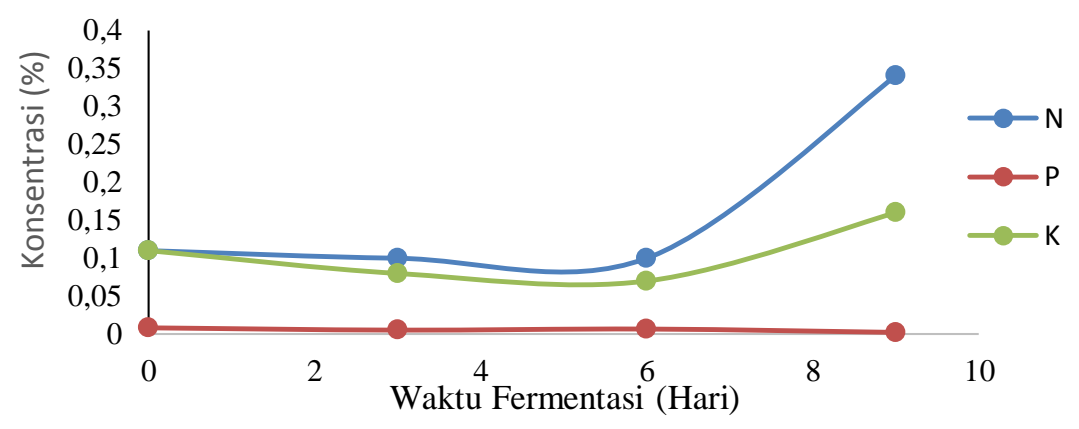

Gambar 2. Pengaruh waktu fermentasi terhadap kandungan nitrogen, fosfor dan kalium dalam pupuk organik cair.

Berdasarkan Gambar 2 terlihat bahwa kadar awal N, P, dan K pada fermentasi hari ke-0 pupuk organik cair mengalami peningkatan setelah dilakukan pengomposan. Peningkatan kadar nitrogen pupuk kandang terjadi karena proses dekomposisi yang dilakukan mikroorganisme yang menghasilkan ammonia dan nitrogen. Nitrogen yang bereaksi dengan air membentuk NO3 - dan H+. Senyawa NO3- bersifat sangat mobile, sangat larut air, dan tidak dapat dipegang oleh koloid tanah serta akan terjadi kehilangan $\mathrm{N}$ dalam bentuk gas, dimana reaksi $\mathrm{NO}_{3}{ }^{-}$menjadi $\mathrm{N} 2$ dan $\mathrm{N}_{2} \mathrm{O}$. Kehilangan $\mathrm{N}$ ini diatasi dengan pembalikan tumpukan pupuk kandang sehingga kadar air berkurang, suplai oksigen yang cukup untuk mikroorganisme mengurai protein menjadi ammonia $\left(\mathrm{NH}_{4}{ }^{+}\right)$, dan proses aerasi [18].

Kandungan fosfor juga dipergaruhi oleh tingginya kandungan nitrogen, semakin tinggi nitrogen yang terkandung maka multiaplikasi mikroorganisme yang merombak fosfor akan meningkat sehingga terjadi kenaikan kandungan fosfor pada pupuk kandang [19]. Bakteri pelarut fosfor umumnya juga dapat melarutkan unsur kalium dalam bahan organik. Kalium digunakan oleh mikroorganisme dalam bahan substrat sebagai katalisator, dengan adanya bakteri dari aktivitasnya akan sangat berpengaruh terhadap peningkatan kandungan kalium. Kalium dapat diikat dan disimpan dalam sel oleh bakteri dan jamur [20]. Namun dalam penelitian ini, kandungan fosfor cenderung tidak berubah selama waktu fermentasi. Padahal komposisi kandungan $\mathrm{P}$ berasal dari berbagai sumber dalam limbah penyulingan minyak nilam dan kotoran ayam. Menurut Ref. [12], pada setiap kenaikan kandungan P berasal dari P lainnya. Sehingga hal ini diyakini sebagai salah satu faktor penurunan kadar fosfor dibandingkan dengan unsur hara lainnya.

\section{Kesimpulan}

Proses pembuatan pupuk organik cair dengan memanfaatkan limbah minyak nilam, bioaktivator EM4 dan penambahan kotoran ayam berhasil meningkatkan unsur hara. Kadar nitrogen (N) maksimum pada variabel EM4/larutan $8 \%$ dengan waktu fermentasi 3 hari yaitu $0,34 \%$. Kadar fosfor (P) maksimum pada variabel EM4/larutan 4\% dengan waktu fementasi 9 hari yaitu $0,10 \%$. Kadar kalium (K) maksimum pada variabel EM4/larutan 2 dan $4 \%$ dengan fermentasi 5 hari yaitu $0,27 \%$.

\section{Ucapan Terima Kasih}

Penulis mengucapkan terima kasih kepada Kementerian Teknologi, Riset, dan Pendidikan Tinggi (RISTEKDIKTI) Republik Indonesia atas pendanaan penelitian di bawah Beasiswa Dosen Universitas Serambi Mekkah Tahun 2016. Penulis juga berterima kasih kepada Laboratorium Teknik Lingkungan, Universitas Serambi Mekkah dan Pusat Penelitian dan Standardisasi Banda Aceh, Indonesia atas penyediaan bahan dan analisis yang telah berstandar nasional. 


\section{Referensi}

[1] E. Sobari, S.T Zahra, "Pembuatan Kompos Dari Limbah Padat Penyulingan Nilam Dengan Metode Fermentasi," J. Iim. llmu dan Teknol. Rekayasa, Vol.2, no. 2, pp.90-97, 2020, doi: 10.31962/jiitr.v2i2.6.

[2] N. K. Dewi, K. Bekti, H. Farida, "Pemanfaatan Serasah Lamun (Seagrass) sebagai Bahan Baku POC," Proceeding Biol. Educ.Conf., vol.13, no 1, pp. 649-652-2016.

[3] W. Hartatik, Husnain, L.R.Widowati, "Peranan Pupuk Organik dalam Peningkatan Produkvitas Tanah dan tamanan," J. Sumberd. Ladan, vol.9, no.2, pp.107-120, 2015.

[4] M. Makiyah, "Analisis Kadar NPK Pupuk Cair Limbah Tahu Dengan Penambah Tanaman Thitonia Diversivolia," IJCS - Indones. J.Chem. Sci., vol. 4, no. 1, 2015.

[5] T. Nur, A. R. Noor, M. Elma, "Pembuatan Pupuk Organik Cair Dari Sampah Organik Rumah Tangga Dengan Penambahan Bioaktivator EM4 (Effective Microorganisms)," Konversi, vol.5 (2): pp.5-12, 2016.

[6] Kementerian Pertanian Republik Indonesia Nomor : 261/KPTS/SR.310/M/4/2019, "Persyaratan teknis minimal pupuk organik, pupuk hayati, dan pembenah tanah," pp.1-18, 2019, [Online]. Available : http://psp.pertanian.go.id/index.php/page/publikasi/418.

[7] D. Adiprakoso, "Pekan ayam dari limbah tempe Menggunakan Bioaktivator EM4 Pekan ayam dari limbah tempe menggunakan Bioaktivator EM4," 2012.

[8] N. K. Fegeria, The use of nutrients in crop plants, 2008.

[9] N. K. Fageri, V.C. Baliger, Y.C. Li, "The role of nutrient efficient plants in improving crop yields in the twenty first century," J. Plant Nutr., vol.31, no 6, pp.1121-1157, 2008, doi: 10.1080/01904160802116068.

[10] T. Salim, Sriharti, "Permanfaatan Ampas Daun Nilam Sebagai Kompos," Pros Semin. Nas.Teknoin 2008 Bid.Tek.Kim. dan Tekst, vol.1, no.1, pp.78-83, 2008.

[11] Lukitawesa, A. Safarudin, R. Millati, M.J. Taherzadeh, C. Niklasson,"'Inhibition of patchouli oil for anaerobic digestion and enhancement in methane production using reverse membrane bioreactors," Renew. Energy, 2017, doi: 10.1016/j.renene.2017.04.068.

[12] E. Sundari, E. Sari, R. Rinaldo, "Pembuatan Pupuk Organik Cair Menggunakan Bioaktivator Biosca dan EM4," pp. 4-8, 2012.

[13] T. R. Ardiningtyas, "Pengaruh Penggunaan Effective Microorganisme (EM4) Dan Molase Terhadap Kualitas Kompos Dalam Pengomposan Sampah Organik," 2013.

[14] A. Asngad, "Inovasi Pupuk Organik Kotoran Ayam Dan Eceng Gondok Dikombinasi Dengan Bioteknologi Mikoriza Bentuk Grranul," J. MIPA Unnes, vol. 36 (1), p. 11522, 2014.

[15] N. Yanqoritha, "Optimasi activator dalam pembuatan kompos organik dari limbah kakao," Majalah llmiah Mektek, pp. 104-108, 2006.

[16] Nurlaila, S, Maesaroh, Novitasari, "Degradasi kandungan Nitrogen Pada pupuk Organik Cair Selama Dalam Penyimpanan, "Bul.Loupe, vol. 14, 14, no 2, pp, 13-18, 2017.

[17] M. L. L Tallo, S. Sio, "Pengaruh Lama Fermentasi terhadap Kualitas Pupuk Bokashi Pada Kotoran Sapi,” Jas, vol.4, no.1, pp. 12-14, 2019,doi : 10.32938/ja.v4il.646.

[18] L. Trivana, A. Y. Pradhana, A. P. Menambangtua, "Optimalisasi Waktu Pengomposan Pupuk Kadang Dari Kotoran Kambing Dan Debu Sabut Kelapa Dengan Bioaktivator EM4," J. Sains dan Teknol. Lingkung., vol.9, no 1, pp. 16-24, 2017.

[19] M. Meriatna, S. Suryati, A. Fahri, "Pengaruh Waktu Fermentasi dan Volume Bioaktivator EM4 (Effective Microorganisme) Pada Pembuatan Pupuk Organik Cair (POC) Dari Limbah Buahbuahan," J.Teknol. Kim. Unimal, vol. (7)1: p.13, 2019, doi: 10.29103/jtku.v.1172.

[20] Y.A. Hidayani, T.B.A Kurnani, E.T. Marlina, "Kualitas Pupuk Cair Hasil Pengolahan Feses Sapi Potong Menggunakan Saccharomyces cereviceae," J. llmu ternak, vol. 11(2), pp. 104-107, 2011. 